\title{
Density of Simulated Americium/Curium Melter Feed Solution
}

by

T. S. Rudisill

Westinghouse Savannah River Company

Savannah River Site

Aiken, South Carolina 29808

DOE Contract No.

This paper was prepared in connection with work done under the above contract number with the U.S. Department of Energy. By acceptance of this paper, the publisher and/or recipient acknowledges the U.S. Government's right to retain a nonexclusive, royalty-free license in and to any copyright covering this paper, along with the right to reproduce and to authorize others to reproduce all or part of the copyrighted paper.

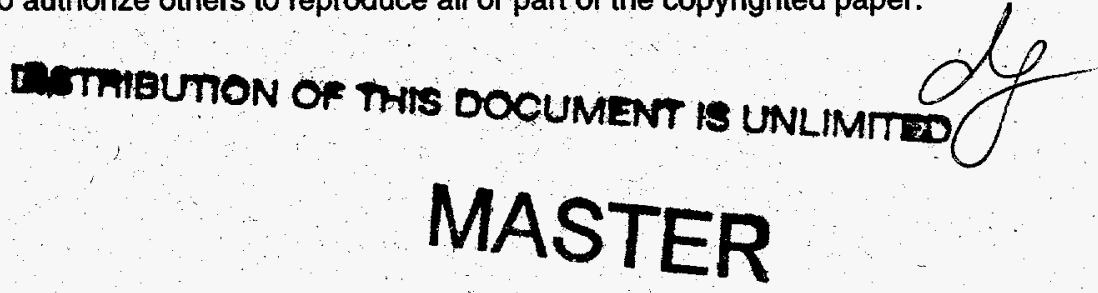




\section{DISCLAMMER}

This report was prepared as an account of work sponsored by an agency of: the United States Government. Neither the United States Government nor any agency thereof, nor any of their employees, makes any warranty, express or implied, or assumes any legal liability or -responsibility for the accuracy, completeness, or usefullness of any information, apparatus, product, or process disclosed, or represents that its use would not infringe privately owned rights. Reference hercin to any specific commercial product, process, or service by trade name, trademark, manufacturer, or otherwise does not necessarily constitute or imply its endorsement, recommendation, or favoring by the United States Government ar any agency thereof. The views and opinions of authors expressed herein do not necessarily state or reflect those of the United States Govemment or any agency thereof.

This report has been reproduced directly from the best available copy.

Available to DOE and DOE contractors from the Office of Scientific and Technical Information, P.O. Box 62, Oak Ridge, TN 37831; prices available from (615) 57.6-8401.

Available to the public from the. National Technical Information Scrvice, U.S. Departmeat of Commerce, 5285 Port Royal Road, Springfield, VA 22161. 


\section{DISCLAIMER}

Portions of this document may be illegible electronic image products. Images are produced from the best available original document. 
WSRC-TR-97-00302

Revision 0

\section{Density of Simulated Americium/Curium Melter Feed Solution (U)}

Tracy S. Rudisill

September 1997

Westinghouse Savannah River Company

P. O. Box 616

Aiken, SC 29808

Prepared by the U. S. Department of Energy under Contract DE-AC09-96SR18500 


\section{Table of Contents}

\section{Section}

Page

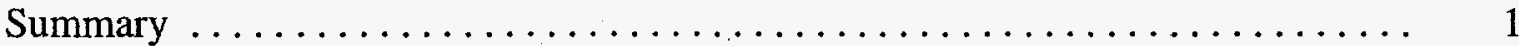

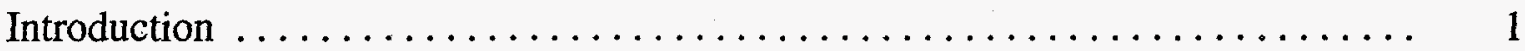

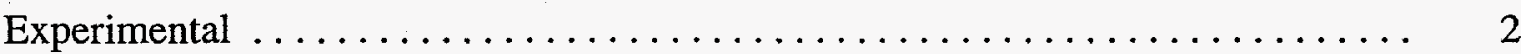

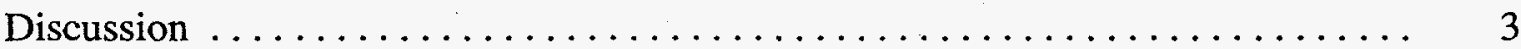

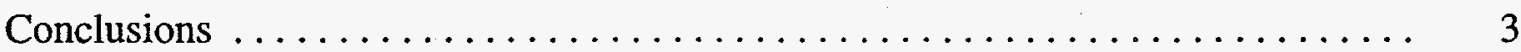

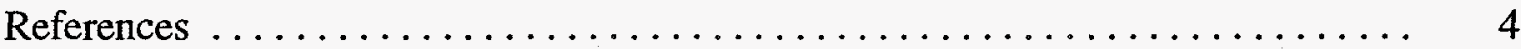

\section{List of Tables}

Table $1 \quad$ Composition of Melter Feed Solution $\ldots \ldots \ldots \ldots \ldots \ldots$

Table 2 Composition of Simulated Am/Cm Solution $\ldots \ldots \ldots \ldots \ldots \ldots$

Table 3 Density of Simulated Am/Cm Feed Solution $\ldots \ldots \ldots \ldots \ldots \ldots$

\section{List of Figures}

Figure $1 \quad$ Water-jacketed Density Cell $\ldots \ldots \ldots \ldots \ldots \ldots \ldots \ldots$

Figure $2 \quad$ Density of Simulated $\mathrm{Am} / \mathrm{Cm}$ Solution $\ldots \ldots \ldots \ldots \ldots \ldots \ldots$

Figure $3 \quad 95 \%$ Confidence Intervals for Data Sets at $20^{\circ} \mathrm{C} \ldots \ldots \ldots \ldots$

Figure $4 \quad 95 \%$ Confidence Intervals for Data Sets at $30^{\circ} \mathrm{C} \ldots \ldots \ldots \ldots \ldots$

\section{List of Appendices}

Appendix A Pipette Calibration Record 
WSRC-TR-97-00302

Revision 0

\title{
Density of Simulated Americium/Curium Melter Feed Solution (U)
}

\author{
Tracy S. Rudisill \\ Westinghouse Savannah River Company \\ Savannah River Site \\ Aiken, SC 29808
}

\section{Summary}

Vitrification will be used to stabilize an americium/curium $(A m / C m)$ solution presently stored in F-Canyon for eventual transport to Oak Ridge National Laboratory and use in heavy isotope production programs. Prior to vitrification, a series of in-tank oxalate precipitation and nitric/oxalic acid washes will be used to separate these elements and lanthanide fission products from the bulk of the uranium and metal impurities present in the solution. Following nitric acid dissolution and oxalate destruction, the solution will be denitrated and evaporated to a dissolved solids concentration of approximately $100 \mathrm{~g} / 1$ (on an oxide basis).

During the $\mathrm{Am} / \mathrm{Cm}$ vitrification, an airlift will be used to supply the concentrated feed solution to a constant head tank which drains through a filter and an in-line orifice to the melter. Since the delivery system is sensitive to the physical properties of the feed, a simulated solution was prepared and used to measure the density as a function of temperature between 20 to $70^{\circ} \mathrm{C}$. The measured density decreased linearly at a rate of $0.0007 \mathrm{~g} / \mathrm{cm}^{3} /{ }^{\circ} \mathrm{C}$ from an average value of 1.2326 $\mathrm{g} / \mathrm{cm}^{3}$ at $20^{\circ} \mathrm{C}$ to an average value of $1.1973 \mathrm{~g} / \mathrm{cm}^{3}$ at $70^{\circ} \mathrm{C}$.

\section{Introduction}

Approximately 15,000 liters of solution containing isotopes of $\mathrm{Am} / \mathrm{Cm}$ are currently stored in F-Canyon Tank 17.1 at the Savannah River Site (SRS). These isotopes were recovered during plutonium-242 production campaigns in the mid and late 1970's. The continued storage of this solution was identified as an item of urgent concern in the Defense Nuclear Facility Safety Board's Recommendation 94-1. To address this concern, the SRS is planning to stabilize the $\mathrm{Am} / \mathrm{Cm}$ in a lanthanide borosilicate glass. The Multi-Purpose Processing Facility in F-Canyon will be used for the vitrification process. Pretreatment operations will be performed in canyon vessels to separate the actinides and lanthanides from alkali and transition metal impurities prior to vitrification. 
The pretreatment operations include a series of in-tank oxalate precipitations followed by nitric/oxalic acid washes to remove the soluble metal impurities. The oxalate precipitate is then dissolved in $8 \mathrm{M}$ nitric acid and the oxalate destroyed by boiling in an evaporator at total reflux. The nitric acid concentration is adjusted to nominally $0.5 \mathrm{M}$ by water stripping and formic acid denitration. The final treatment prior to vitrification is an evaporation step to concentrate the dissolved solids to approximately $100 \mathrm{~g} / 1$ (on an oxide basis). The estimated solution volume and nitric acid concentration following concentration are 1131 liters and approximately $3 \mathrm{M} .^{1}$

Once the desired concentration of dissolved solids is reached, the $\mathrm{Am} / \mathrm{Cm}$ solution is transferred by vacuum to one of two slab tanks in the MPPF. When the melter is operational, an airlift is used to supply a constant head tank above the melter. The head tank overflows back to a slab tank and feeds the melter through a filter and an in-line orifice plate. The orifice is sized to delivery the proper flowrate of solution to the melter. The design of the feed delivery system is sensitive to the physical properties of the concentrated solution such as density and viscosity. For this reason, a simulated $\mathrm{Am} / \mathrm{Cm}$ solution containing nominally $100 \mathrm{~g} / \mathrm{l}$ dissolved solids was prepared and used to measure the density as a function of temperature. The composition of the solution was based on material balance calculations performed for the pretreatment operations. The calculations assumed three successive oxalate precipitations followed by two $0.25 \mathrm{M}$ oxalic acid/0.5M nitric acid washes. The dip tube of the steam transfer jet was assumed to be 24-inches above the bottom of the tank. The estimated composition following the concentration step is shown in Table 1.

\section{Experimental}

Two liters of simulated $\mathrm{Am} / \mathrm{Cm}$ feed solution were prepared by dissolving either the materials listed in Table 1 in $3 \mathrm{M}$ nitric acid or combinations of other starting materials to achieve the desired chemical species. Simplifying assumptions used in the solution preparation include:

1. oxide mass of terbium, dysprosium, holmium, erbium, thulium, ytterbium, and lutetium was redistributed as lanthanum, cerium, praseodymium, neodymium, samarium, europium, and gadolinium oxides,

2. oxide masses of americium and curium were added as erbium oxide,

3. oxide masses of uranium, neptunium, and plutonium were added as cerium oxide,

4. ferric oxalate was added as ferric nitrate and oxalic acid,

5. ferric phosphate was added as ferric nitrate and phosphoric acid,

6. ferric chloride was added as ferric nitrate and hydrochloric acid, and

7. zinc nitrate was added as zinc oxide previously dissolved in $3 \mathrm{M}$ nitric acid.

A summary of the starting materials, amounts of each reagent, and calculated solution concentrations is shown in Table 2. 
The density of the simulated $\mathrm{Am} / \mathrm{Cm}$ solution was measured by initially transferring approximately $300 \mathrm{ml}$ of the simulant to a water-jacketed cell (see Figure 1). The temperature of the solution was cooled or heated using a Fisher Scientific Programmable Circulator: A calibrated mercury-filled thermometer was used to manually control the cell temperature. Once the solution was at the desired temperature, a $1 \mathrm{ml}\left(\mathrm{cm}^{3}\right)$ sample of the solution was removed using a calibrated pipette. A copy of the pipette calibration record is shown in Appendix A. The solution was transferred to a tared $10 \mathrm{ml}$ beaker on a calibrated analytical balance. The mass of the solution was then recorded. Measurements were made at solution temperatures of 20,30,40, 50,60 , and $70^{\circ} \mathrm{C}$.

\section{Discussion}

The mass of each $1 \mathrm{ml}\left(\mathrm{cm}^{3}\right)$ aliquot of the simulated Am/Cm solution at $20,30,40,50,60$, and $70^{\circ} \mathrm{C}$ is reported in Table 3 . The density reported for each measurement was calculated using a mean value of $1.0030 \mathrm{ml}\left(\mathrm{cm}^{3}\right)$ for the volume transferred by the calibrated pipette. The mean value, standard deviation, and $95 \%$ confidence limits for the density is also reported for each temperature. The mean value of the density as a function of the simulated solution temperature is shown on Figure 2. The error bars shown on the plot are \pm 1 standard deviation for the mean densities. The regression line for the data is presented as equation (1).

$$
\operatorname{Density}\left(\mathrm{g} / \mathrm{cm}^{3}\right)=1.2467-7.0078 \mathrm{E}^{-4} \text { Temperature }\left({ }^{\circ} \mathrm{C}\right)
$$

The three sets of ten measurements made at 20 and $30^{\circ} \mathrm{C}$ compared to a single set for the other temperatures (see Table 3 ) were the results of discovering a positive bias with the volume delivered by the calibrated pipette as the solution temperature increased. Initially the same pipette tip was reused for all the measurements at a given temperature. When measurements at $40^{\circ} \mathrm{C}$ were performed, the density of the solution noticeably increased from one measurement to the next. This was attributed to a slight expansion of the plastic pipette tip volume due to the solution temperature. As a result of this discovery, a new pipette tip was used for each measurement and the measurements at 20 and $30^{\circ} \mathrm{C}$ were repeated two additional times. Construction of $95 \%$ confidence intervals for the average densities calculated from the three data sets at 20 and $30^{\circ} \mathrm{C}$ (see Figures 3 and 4, respectively) shows statistical differences; however, the data sets at each temperature were pooled since there was no technical basis for discarding an outlying data set.

\section{Conclusions}

A nonradioactive solution was prepared to simulate the physical properties of the $\mathrm{Am} / \mathrm{Cm}$ feed solution just prior to vitrification. The density of the simulant was measured as function of temperature between 20 and $70^{\circ} \mathrm{C}$. The density decreased linearly at rate of $0.0007 \mathrm{~g} / \mathrm{cm}^{3} /{ }^{\circ} \mathrm{C}$ from an average value of $1.2326 \mathrm{~g} / \mathrm{cm}^{3}$ at $20^{\circ} \mathrm{C}$ to an average value of $1.1973 \mathrm{~g} / \mathrm{cm}^{3}$ at $70^{\circ} \mathrm{C}$. 
WSRC-TR-97-00302

Revision 0

\section{References}

1. T. S. Rudisill, Pretreatment of Americium/Curium Solutions for Vitrification (U), External Report WSRC-TR-96-0074, Westinghouse Savannah River Company, Aiken, SC (March 1996). 
WSRC-TR-97-00302

Revision 0

Table 1 Composition of Melter Feed Stream

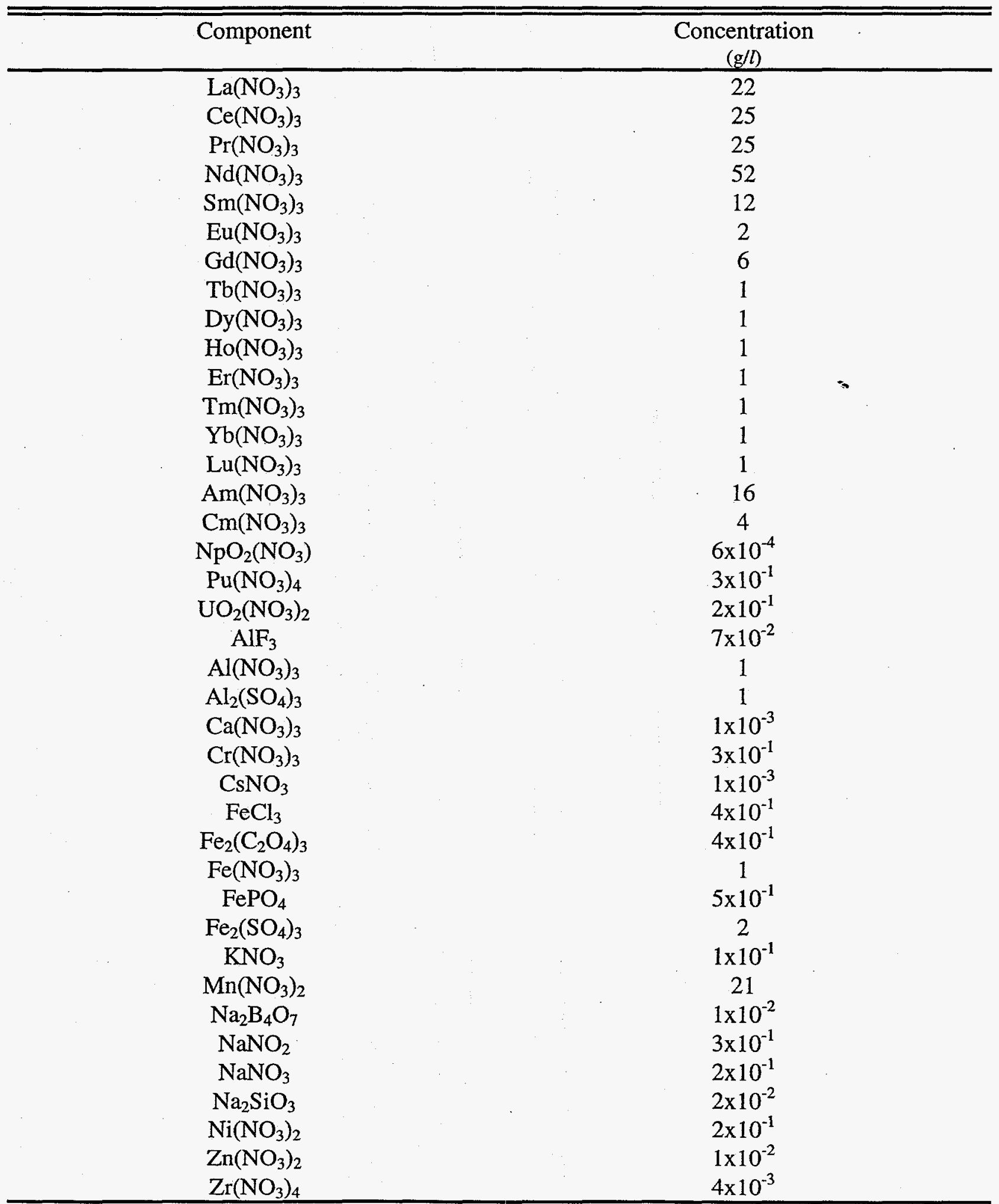


Table 2 Composition of Simulated Am/Cm Solution

\begin{tabular}{|c|c|c|c|c|}
\hline $\begin{array}{l}\text { Compound } \\
\text { in Solution }\end{array}$ & Reagent & $\begin{array}{c}\text { Reagent } \\
\text { Mass } \\
(\mathrm{g}) \\
\end{array}$ & $\begin{array}{c}\text { Compound } \\
\text { Concentration } \\
(\mathrm{g} / \mathrm{l})\end{array}$ & $\begin{array}{c}\text { Oxide Basis } \\
\text { Concentration } \\
(\mathrm{g} / \mathrm{l})\end{array}$ \\
\hline $\mathrm{La}\left(\mathrm{NO}_{3}\right)_{3}$ & $\mathrm{La}\left(\mathrm{NO}_{3}\right)_{3} \cdot 6 \mathrm{H}_{2} \mathrm{O}$ & 60.3628 & 22.6473 & 11.3546 \\
\hline $\mathrm{Ce}\left(\mathrm{NO}_{3}\right)_{3}$ & $\mathrm{Ce}\left(\mathrm{NO}_{3}\right)_{3} \cdot 6 \mathrm{H}_{2} \mathrm{O}$ & 70.3036 & 26.4015 & 13.2859 \\
\hline $\operatorname{Pr}\left(\mathrm{NO}_{3}\right)_{3}$ & $\operatorname{Pr}\left(\mathrm{NO}_{3}\right)_{3} \cdot 6 \mathrm{H}_{2} \mathrm{O}$ & 68.4910 & 25.7362 & 12.9819 \\
\hline $\mathrm{Nd}\left(\mathrm{NO}_{3}\right)_{3}$ & $\mathrm{Nd}\left(\mathrm{NO}_{3}\right)_{3} \cdot 6 \mathrm{H}_{2} \mathrm{O}$ & 140.6339 & 52.9775 & 26.9879 \\
\hline $\mathrm{Sm}\left(\mathrm{NO}_{3}\right)_{3}$ & $\mathrm{Sm}\left(\mathrm{NO}_{3}\right)_{3} \cdot 6 \mathrm{H}_{2} \mathrm{O}$ & 33.9039 & 12.8293 & 6.6501 \\
\hline $\mathrm{Eu}\left(\mathrm{NO}_{3}\right)_{3}$ & $\mathrm{Eu}\left(\mathrm{NO}_{3}\right)_{3} \cdot 5 \mathrm{H}_{2} \mathrm{O}$ & 8.6445 & 3.2749 & 1.7050 \\
\hline $\mathrm{Gd}\left(\mathrm{NO}_{3}\right)_{3}$ & $\mathrm{Gd}\left(\mathrm{NO}_{3}\right)_{3} \cdot 6 \mathrm{H}_{2} \mathrm{O}$ & 17.6970 & 6.7294 & 3.5533 \\
\hline $\mathrm{Er}\left(\mathrm{NO}_{3}\right)_{3}$ & $\mathrm{Er}\left(\mathrm{NO}_{3}\right)_{3} \cdot 5 \mathrm{H}_{2} \mathrm{O}$ & 60.1385 & 23.0244 & 12.4652 \\
\hline $\mathrm{AlF}_{3}$ & $\mathrm{AlF}_{3}$ & 0.1469 & 0.0735 & 0.0446 \\
\hline $\mathrm{Al}\left(\mathrm{NO}_{3}\right)_{3}$ & $\mathrm{Al}\left(\mathrm{NO}_{3}\right)_{3} \cdot 9 \mathrm{H}_{2} \mathrm{O}$ & 2.2394 & 0.6358 & 0.1522 \\
\hline $\mathrm{Al}_{2}\left(\mathrm{SO}_{4}\right)_{3}$ & $\mathrm{Al}_{2}\left(\mathrm{SO}_{4}\right)_{3} \cdot 18 \mathrm{H}_{2} \mathrm{O}$ & 3.8421 & 0.9863 & 0.2939 \\
\hline $\mathrm{Ca}\left(\mathrm{NO}_{3}\right)_{3}$ & $\mathrm{Ca}\left(\mathrm{NO}_{3}\right)_{3} \cdot 4 \mathrm{H}_{2} \mathrm{O}$ & 0.1877 & 0.0652 & 0.0223 \\
\hline $\mathrm{Cr}\left(\mathrm{NO}_{3}\right)_{3}$ & $\mathrm{Cr}\left(\mathrm{NO}_{3}\right)_{3} \cdot 9 \mathrm{H}_{2} \mathrm{O}$ & 1.0677 & 0.3175 & 0.1014 \\
\hline $\mathrm{CsNO}_{3}$ & $\mathrm{CsNO}_{3}$ & 0.0028 & 0.0014 & 0.0010 \\
\hline $\mathrm{FeCl}_{3}$ & $\begin{array}{c}\mathrm{Fe}\left(\mathrm{NO}_{3}\right)_{3} \cdot 9 \mathrm{H}_{2} \mathrm{O} \\
37.2 \mathrm{wt} \% \mathrm{HCl}\end{array}$ & $\begin{array}{r}(1) \\
1.1 \mathrm{ml}\end{array}$ & 0.3898 & 0.1771 \\
\hline $\mathrm{Fe}_{2}\left(\mathrm{C}_{2} \mathrm{O}_{4}\right)_{3}$ & $\begin{array}{c}\mathrm{Fe}\left(\mathrm{NO}_{3}\right)_{3} \cdot 9 \mathrm{H}_{2} \mathrm{O} \\
\mathrm{H}_{2} \mathrm{C}_{2} \mathrm{O}_{4} \cdot 2 \mathrm{H}_{2} \mathrm{O}\end{array}$ & $\begin{array}{r}(1) \\
0.8121\end{array}$ & 0.4046 & 0.1720 \\
\hline $\mathrm{Fe}\left(\mathrm{NO}_{3}\right)_{3}$ & $\mathrm{Fe}\left(\mathrm{NO}_{3}\right)_{3} \cdot 9 \mathrm{H}_{2} \mathrm{O}$ & 7.5764 & 0.5082 & 0.1705 \\
\hline $\mathrm{FePO}_{4}$ & $\begin{array}{c}\mathrm{Fe}\left(\mathrm{NO}_{3}\right)_{3} \cdot 9 \mathrm{H}_{2} \mathrm{O} \\
85.5 \mathrm{wt} \% \mathrm{H}_{3} \mathrm{PO}_{4}\end{array}$ & $\begin{array}{r}(1) \\
0.4 \mathrm{ml}\end{array}$ & 0.4464 & 0.2363 \\
\hline $\mathrm{Fe}_{2}\left(\mathrm{SO}_{4}\right)_{3}$ & $77 \mathrm{wt} \% \mathrm{Fe}_{2}\left(\mathrm{SO}_{4}\right)_{3}$ & 5.3950 & 2.0771 & 0.8295 \\
\hline $\mathrm{KNO}_{3}$ & $\mathrm{KNO}_{3}$ & 0.2696 & 0.1348 & 0.0628 \\
\hline $\mathrm{Mn}\left(\mathrm{NO}_{3}\right)_{2}$ & $\mathrm{Mn}\left(\mathrm{NO}_{3}\right)_{2} \cdot 6 \mathrm{H}_{2} \mathrm{O}$ & 66.2899 & 20.6634 & 8.1913 \\
\hline $\mathrm{Na}_{2} \mathrm{~B}_{4} \mathrm{O}_{7}$ & $\mathrm{Na}_{2} \mathrm{~B}_{4} \mathrm{O}_{7} \cdot 10 \mathrm{H}_{2} \mathrm{O}$ & 0.0439 & 0.0116 & 0.0036 \\
\hline $\mathrm{NaNO}_{2}$ & $\mathrm{NaNO}_{2}$ & 0.6047 & 0.3024 & 0.1358 \\
\hline $\mathrm{NaNO}_{3}$ & $\mathrm{NaNO}_{3}$ & 0.3916 & 0.1958 & 0.0714 \\
\hline $\mathrm{Na}_{2} \mathrm{SiO}_{3}$ & $\mathrm{Na}_{2} \mathrm{SiO}_{3} \cdot 9 \mathrm{H}_{2} \mathrm{O}$ & 0.0898 & 0.0193 & 0.0098 \\
\hline $\mathrm{Ni}\left(\mathrm{NO}_{3}\right)_{2}$ & $\mathrm{Ni}\left(\mathrm{NO}_{3}\right)_{2} \cdot 6 \mathrm{H}_{2} \mathrm{O}$ & 0.4980 & 0.1727 & 0.0527 \\
\hline $\mathrm{Zn}\left(\mathrm{NO}_{3}\right)_{2}$ & $\mathrm{ZnO}$ & 0.0157 & 0.0183 & 0.0079 \\
\hline $\mathrm{Zr}\left(\mathrm{NO}_{3}\right)_{4}$ & $\mathrm{Zr}\left(\mathrm{NO}_{3}\right)_{4}$ & 0.0074 & 0.0037 & 0.0014 \\
\hline Total (2) & & & & 99.7211 \\
\hline
\end{tabular}

(1) The amount of acid was the limiting reagent.

(2) The total includes $0.0117 \mathrm{~g} \mathrm{~B}_{2} \mathrm{O}_{5}$ and $0.0095 \mathrm{~g} \mathrm{SiO}_{2}$ from $\mathrm{Na}_{2} \mathrm{~B}_{4} \mathrm{O}_{7}$ and $\mathrm{Na}_{2} \mathrm{SiO}_{3}$, respectively. 
Table 3 Density of Simulated Am/Cm Feed Solution

\begin{tabular}{|c|c|c|c|c|c|c|}
\hline \multicolumn{2}{|c|}{$20^{\circ} \mathrm{C}$} & \multicolumn{2}{|c|}{$30^{\circ} \mathrm{C}$} & \multicolumn{3}{|c|}{$40^{\circ} \mathrm{C}$} \\
\hline $\begin{array}{c}\text { Mass } \\
(\mathrm{g})\end{array}$ & $\begin{array}{l}\text { Density } \\
\left(\mathrm{g} / \mathrm{cm}^{3}\right)\end{array}$ & $\begin{array}{c}\text { Mass } \\
(\mathrm{g}) \\
\end{array}$ & $\begin{array}{l}\text { Density } \\
\left(\mathrm{g} / \mathrm{cm}^{3}\right)\end{array}$ & $\begin{array}{c}\text { Mass } \\
(\mathrm{g})\end{array}$ & & $\begin{array}{l}\text { Density } \\
\left(\mathrm{g} / \mathrm{cm}^{3}\right)\end{array}$ \\
\hline 1.2341 & 1.2304 & 1.2313 & 1.2276 & 1.2238 & & 1.2201 \\
\hline 1.2382 & 1.2345 & 1.2370 & 1.2333 & 1.2183 & & 1.2147 \\
\hline 1.2356 & 1.2319 & 1.2363 & 1.2326 & 1.2221 & & 1.2184 \\
\hline 1.2376 & 1.2339 & 1.2329 & 1.2292 & 1.2231 & & 1.2194 \\
\hline 1.2380 & 1.2343 & 1.2344 & 1.2307 & 1.2230 & & 1.2193 \\
\hline 1.2386 & 1.2349 & 1.2371 & 1.2334 & 1.2191 & & 1.2155 \\
\hline 1.2429 & 1.2392 & 1.2401 & 1.2364 & 1.2197 & & 1.2161 \\
\hline 1.2404 & 1.2367 & 1.2351 & 1.2314 & 1.2202 & & 1.2166 \\
\hline 1.2356 & 1.2319 & 1.2309 & 1.2272 & 1.2222 & $*$ & 1.2185 \\
\hline 1.2373 & 1.2336 & 1.2371 & 1.2334 & 1.2228 & & 1.2191 \\
\hline 1.2372 & 1.2335 & 1.2281 & 1.2244 & & & \\
\hline 1.2354 & 1.2317 & 1.2280 & 1.2243 & & & \\
\hline 1.2364 & 1.2327 & 1.2282 & 1.2245 & & & \\
\hline 1.2379 & 1.2342 & 1.2328 & 1.2291 & & & \\
\hline 1.2382 & 1.2345 & 1.2288 & 1.2251 & & & \\
\hline 1.2401 & 1.2364 & 1.2305 & 1.2268 & & & \\
\hline 1.2361 & 1.2324 & 1.2287 & 1.2250 & & & \\
\hline 1.2403 & 1.2366 & 1.2298 & 1.2261 & & & \\
\hline 1.2399 & 1.2362 & 1.2275 & 1.2238 & & & \\
\hline 1.2383 & 1.2346 & 1.2240 & 1.2203 & & & \\
\hline 1.2311 & 1.2274 & 1.2248 & 1.2211 & & & \\
\hline 1.2327 & 1.2290 & 1.2252 & 1.2215 & & & \\
\hline 1.2333 & 1.2296 & 1.2229 & 1.2192 & & & \\
\hline 1.2320 & 1.2283 & 1.2250 & 1.2213 & & & \\
\hline 1.2336 & 1.2299 & 1.2254 & 1.2217 & & & \\
\hline 1.2335 & 1.2298 & 1.2244 & 1.2207 & & & \\
\hline 1.2326 & 1.2289 & 1.2242 & 1.2205 & & & \\
\hline 1.2343 & 1.2306 & 1.2261 & 1.2224 & & & \\
\hline 1.2347 & 1.2310 & 1.2149 & 1.2113 & & & \\
\hline 1.2345 & 1.2308 & 1.2386 & 1.2349 & & & \\
\hline Mean & 1.2326 & & 1.2260 & & & 1.2178 \\
\hline Std Dev & 0.0029 & & 0.0057 & & & 0.0019 \\
\hline $95 \% \mathrm{CL}$ & 0.0059 & & 0.0117 & & & 0.0039 \\
\hline
\end{tabular}


WSRC-TR-97-00302

Revision 0

Table 3 Continued

\begin{tabular}{cccccc}
\hline \hline \multicolumn{2}{c}{$50^{\circ} \mathrm{C}$} & \multicolumn{2}{c}{$60^{\circ} \mathrm{C}$} & \multicolumn{2}{c}{$70^{\circ} \mathrm{C}$} \\
$(\mathrm{g})$ & $\begin{array}{c}\text { Density } \\
\left(\mathrm{g} / \mathrm{cm}^{3}\right)\end{array}$ & $\begin{array}{c}\text { Mass } \\
(\mathrm{g})\end{array}$ & $\begin{array}{c}\text { Density } \\
\left(\mathrm{g} / \mathrm{cm}^{3}\right)\end{array}$ & $\begin{array}{c}\text { Mass } \\
(\mathrm{g})\end{array}$ & $\begin{array}{c}\text { Density } \\
\left(\mathrm{g} / \mathrm{cm}^{3}\right)\end{array}$ \\
\hline 1.2118 & 1.2082 & 1.2057 & 1.2021 & 1.1931 & 1.1895 \\
1.2165 & 1.2129 & 1.2074 & 1.2038 & 1.2013 & 1.1977 \\
1.2176 & 1.2140 & 1.2073 & 1.2037 & 1.1988 & 1.1952 \\
1.2125 & 1.2089 & 1.2082 & 1.2046 & 1.1980 & 1.1944 \\
1.2162 & 1.2126 & 1.2087 & 1.2051 & 1.2062 & 1.2026 \\
1.2142 & 1.2106 & 1.2074 & 1.2038 & 1.2010 & 1.1974 \\
1.2153 & 1.2117 & 1.2139 & 1.2103 & 1.2022 & 1.1986 \\
1.2147 & 1.2111 & 1.2142 & 1.2106 & 1.2046 & 1.2010 \\
1.2152 & 1.2116 & 1.2094 & 1.2058 & 1.1958 & 1.1922 \\
1.2126 & 1.2090 & 1.2113 & 1.2077 & 1.2083 & 1.2047 \\
\hline Mean & 1.2111 & & 1.2058 & & 1.1973 \\
Std Dev & 0.0019 & & 0.0029 & & 0.0047 \\
$95 \%$ CL & 0.0043 & & 0.0069 & & 0.0106 \\
\hline
\end{tabular}


Figure 1 Water-jacketed Density Cell

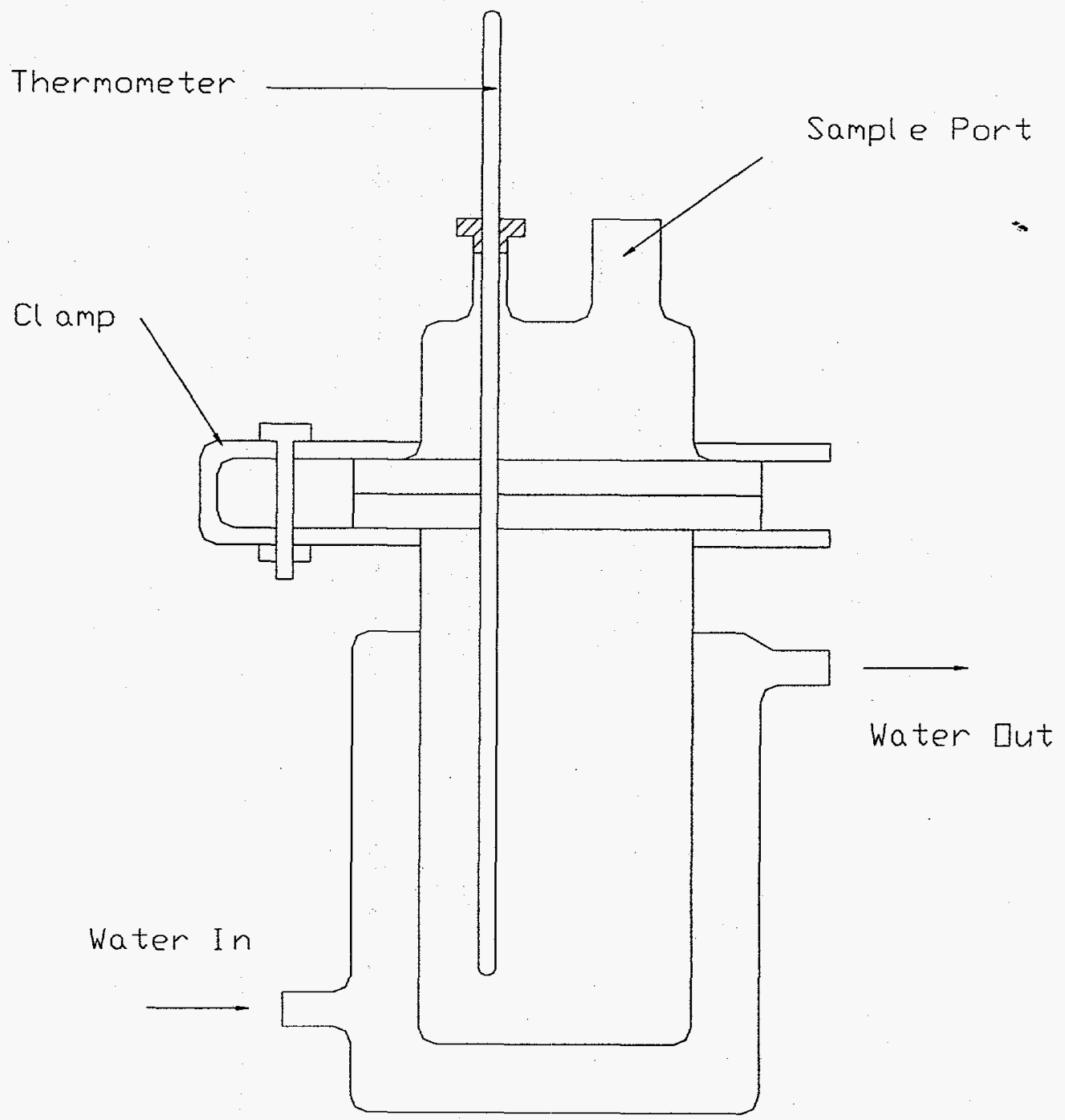


Figure 2 Density of Simulated Am/Cm Solution

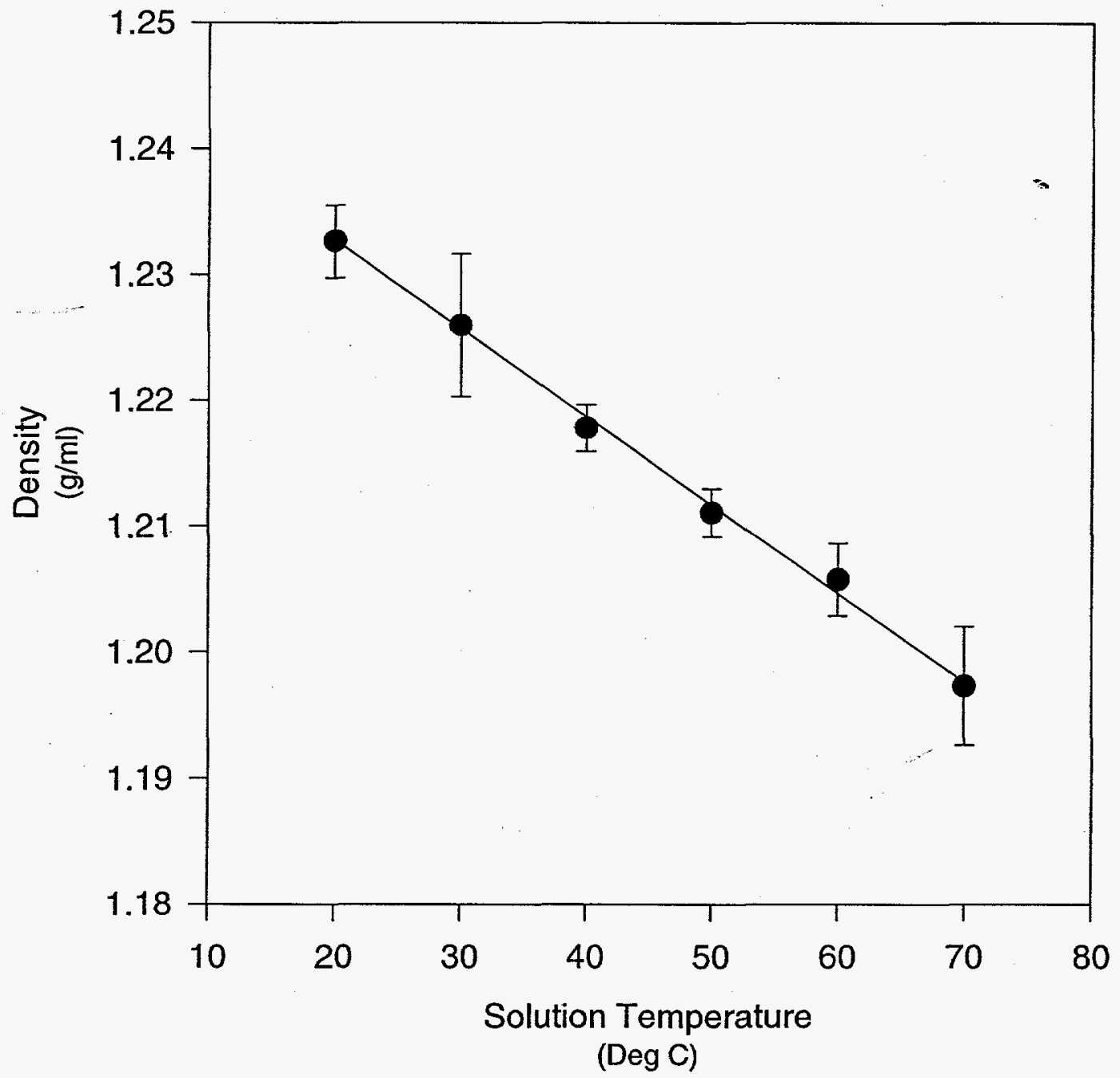



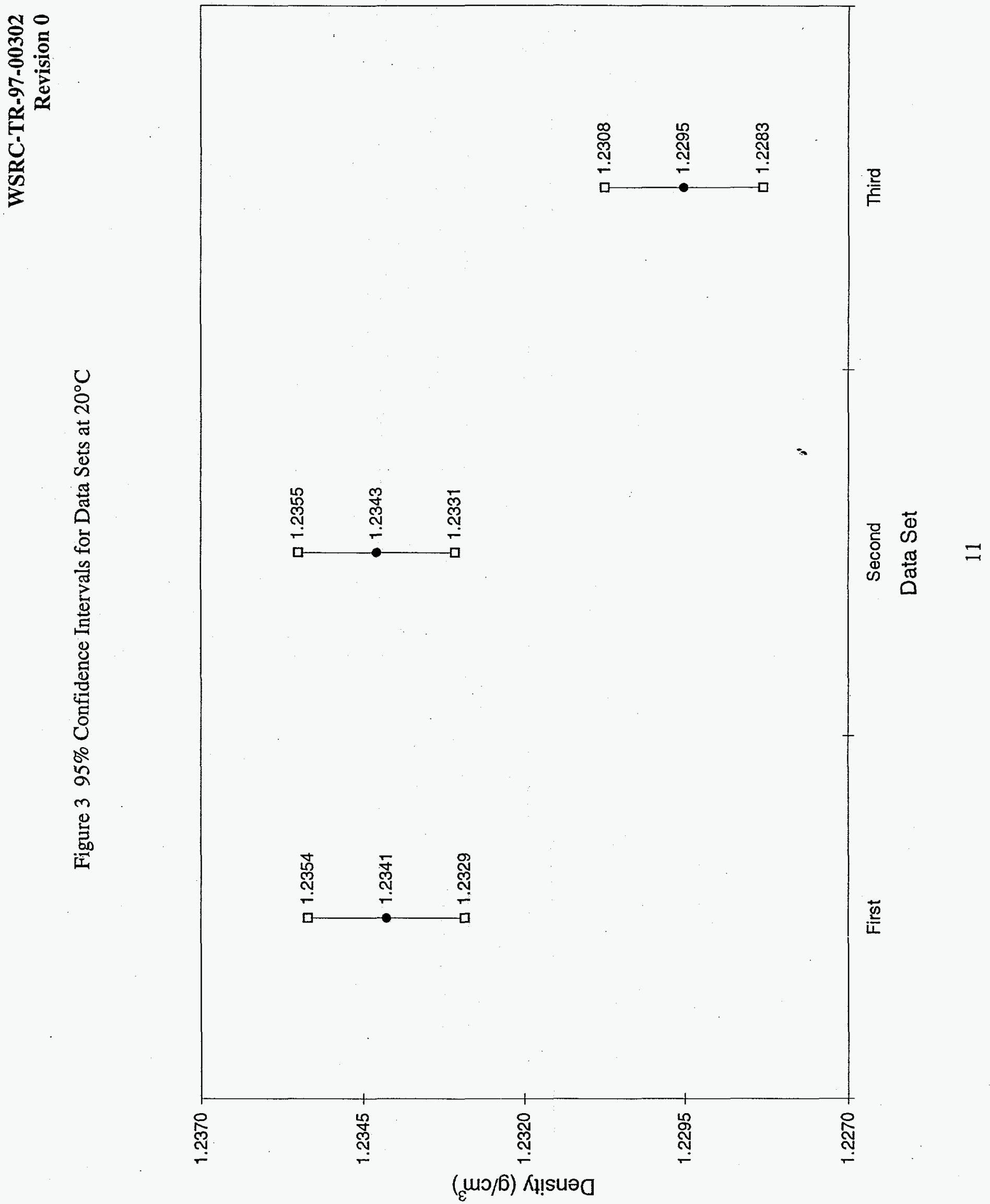

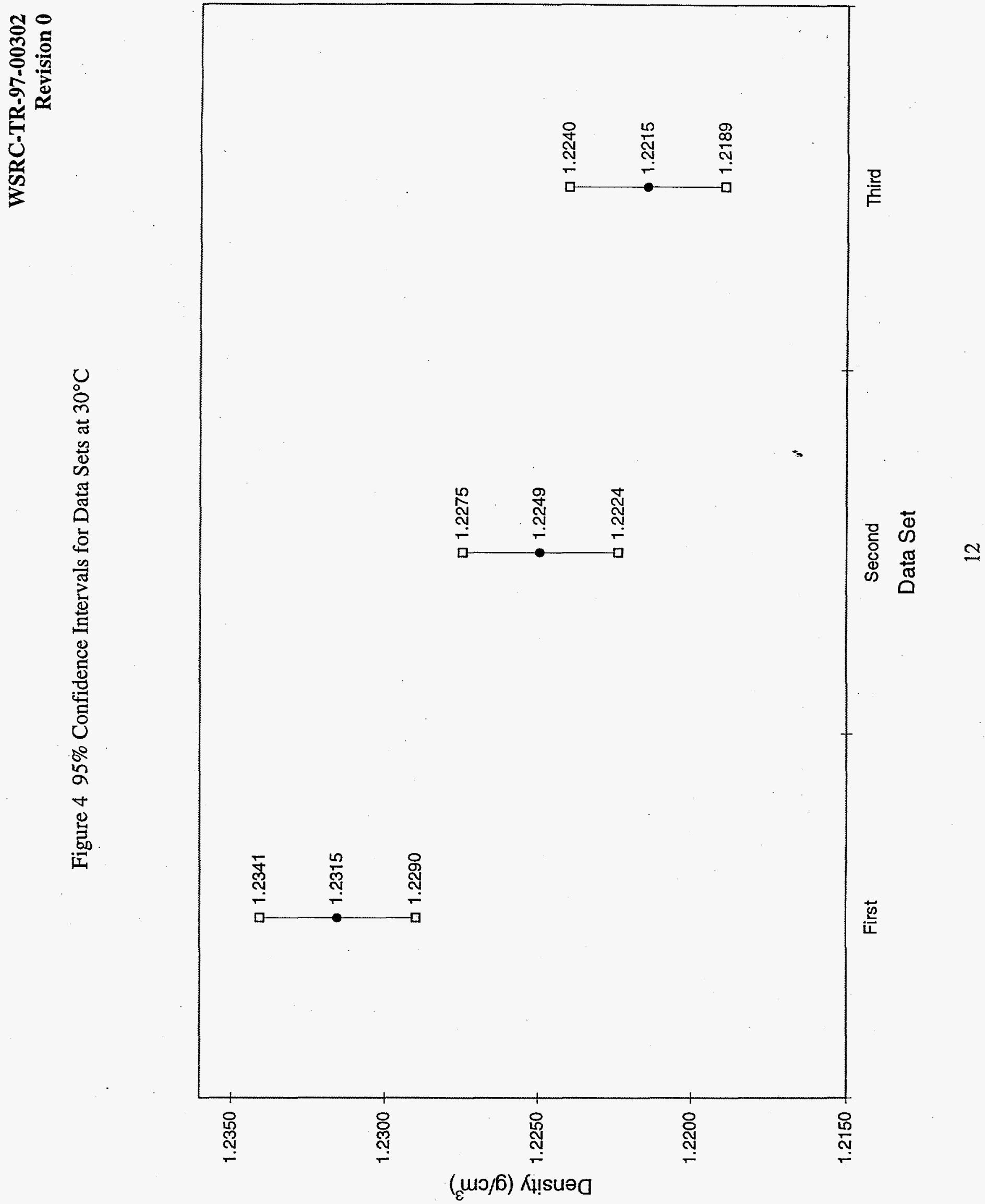
WSRC-TR-97-00302

Revision 0

Appendix A Pipette Calibration Record

\begin{tabular}{|c|c|c|c|c|c|}
\hline & \multicolumn{2}{|c|}{ Data Required per QAP 12-1, Rev 5.} & \multicolumn{3}{|c|}{ Check One } \\
\hline & M\&TE \# of Balance Used for Calib.: & AD0041 & & Pass & Fail \\
\hline & Balance Calibration Expiration Date: & $3 / 11 / 97$ & As Found Results: & $\bar{x}$ & \\
\hline & Pipet Calibration Procedure: & ADS 1000, Rev. 6 & As Left Results: & $\bar{X}$ & \\
\hline & Pipet M\&TE ID \#: & J18060D & & Hot & Cold \\
\hline & Pipet Manufacturer: & RAININ & Lab Station: & & $\bar{x}$ \\
\hline & Pipet Model Number: & P1000 & & $\overline{\text { Yes }}$ & $\overline{\text { No }}$ \\
\hline & Volume: & -1.0000 & New Pipet? & & $\bar{x}$ \\
\hline & Date of this Calibration: & $1 / 10 / 97$ & & & \\
\hline & Lab \# (where pipet is used): & B137 & & & \\
\hline & Date Pipet Calibration Expires: & $4 / 10 / 97$ & & $=$ & \\
\hline & Manual Calibration Results: & & QC LIMITS: & \%BIAS & \%ASD \\
\hline $1-$ & 1.0024 & STDEV & & 0.8 & 0.6 \\
\hline $2-$ & 1.0038 & 0.0019 & & & \\
\hline $3-$ & 1.0049 & & & & \\
\hline $4-$ & 1.0042 & MEAN & & & \\
\hline $5-$ & 1.0057 & 01.0030 & & & \\
\hline $6-$ & 1.0045 & & & & \\
\hline 7- & 0.9995 & \%BIAS & & & \\
\hline 8- & 1.0008 & 0.30 & & & \\
\hline $9-$ & 1.0023 & & & & \\
\hline $10-$ & 1.0021 & $\%$ RSD & & & \\
\hline & & 0.19 & & & \\
\hline & & & & & \\
\hline & Pipette passes QA I & imits. & & & \\
\hline & & & & & \\
\hline & Calibrated by: & CY Tilley & & & \\
\hline & Signature or Initial: & $\operatorname{cis}$ & & & \\
\hline & & & & & \\
\hline & & & & & \\
\hline & 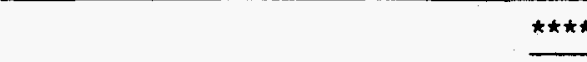 & NOTICE & & & \\
\hline & "As found" readings are when no : & djustment has been $\mathrm{m}$ & de to the pipet, "as le & $\mathrm{ft}^{\prime \prime}$ are if & \\
\hline & adjustment has been made. If adjus & nents are made, turn & both the before and & after resi & \\
\hline & & & & & \\
\hline & *Initial or sign the printout & nd any other official & cords turned in. * & & \\
\hline & & & & & \\
\hline
\end{tabular}

